\title{
SISTEM PEMBAYARAN PARKIR MENGGUNAKAN NEAR FIELD COMMUNICATION BERBASIS ANDROID DAN TEKNOLOGI INTERNET OF THINGS
}

\author{
Dody Ichwana Putra1,*, Wanda Syahputra² \\ 1 Jurusan Sistem Komputer Fakultas Teknologi Universitas Andalas \\ 2Jurusan Sistem Informasi Fakultas Teknologi Informasi Universitas Andalas \\ (corresponding author) dody.ichwana@fti.unand.ac.id*
}

\begin{abstract}
This paper proposes a design of the parking payment system using NFC (Near Field Communication) and GPS (Global Position System) to create parking payment method smarter. The main contributions of this work is to apply the concept of pervasive computing and the Internet of Things (IOT) in the construction of the parking system, so that users become more comfortable to park their vehicles. This is achieved by a Wifi installed parking location and a unique SSID name. The system will perform sensing to users who enter the parking location using the IMEl. Parking payments using applications on smartphones with NFC Enable a way brought closer to the NFC reader in the system. Users tapping on a smartphone with NFC reader to Enable NFC to perform early initialization process the vehicle park will record the user ID, date, and the balance of virtual money. Apps on smartphones will record the parking location coordinates corresponding vehicle parking location selected by the user. Furthermore, the application will help users find the location of the vehicle when user forgotten the position. Parking payment system in this study has been successfully built by avoiding the use of paper tickets so it will be easier for users and more environmentally friendly.
\end{abstract}

\section{Keyword- Smart Parking Payment, NFC, Pervasive Computing, IoT, EMEI Sensing}

Intisari- Makalah ini menjelaskan rancang bangun sistem pembayaran parkir menggunakan NFC (Near Field Communication) dan GPS (Global Position System) untuk menciptakan metode pembayaran parkir yang lebih cerdas. Kontribusi yang diberikan dari hasil penelitian adalah menerapkan konsep pervasive computing dan Internet of Things (IoT) di dalam pembangunan sistem parkir, sehingga proses pembayaran parkir menjadi lebh efektif. Lokasi parkir dipasang wifi dan nama SSID yang unik. Sistem akan melakukan sensing kepada pengguna yang memasuki lokasi parkir menggunakan IMEI. Pembayaran parkir menggunakan aplikasi pada smartphone dengan NFC Enable dengan cara didekatkan pada NFC reader pada sistem. Pengguna melakukan tap pada smartphone dengan NFC Enable ke NFC reader untuk melakukan proses inisialisasi awal parkir kendaraan yang akan mencatat ID pengguna, data waktu, dan saldo uang dijital. Aplikasi pada perangkat pintar akan mencatat koordinat lokasi parkir kendaraan sesuai lokasi parkir yang dipilih oleh pengguna. Selanjutnya, aplikasi akan membantu pengguna menemukan lokasi kendaraan ketika penguuna terlupa. Sistem pembayaran parkir pada penelitian ini telah berhasil dibangun dengan menghindari penggunaan kertas untuk tiket sehingga akan lebih memudahkan pengguna dan lebih ramah lingkungan.

Kata Kunci-Sistem Pembayaran Parkir Cerdas, NFC, Pervasive Computing, IoT, EMEI Sensing

I. PENDAHULUAN

Peningkatan jumlah kendaran semakin pesat dari tahun ke tahun di perkotaan, hal ini seiring dengan meningkatnya kebutuhan terhadap lahan parkir di dalam kota. Selain di dalam kota, lahan parkir juga meningkat di daerah-daerah yang menjadi lokasi wisata [1]. Ketersediaan lokasi parkir yang didukung oleh sistem pengelolaan parkir yang baik akan membuat pengunjung menjadi lebih nyaman. Salah satu faktor pendukung pengelolaan parkir yang benar adalah pembayaran parkir yang jelas [1] [2]. Masalah kesalahan penghitungan biaya parkir secara manual sering terjadi, disamping lamanya waktu yang dibutuhkan untuk antri saat melakukan pembayaran [2]. Dari segi pengelola parkir, biaya yang dikeluarkan untuk melakukan pengontrolan biaya parkir menjadi lebih besar ketika dilakukan secara manual oleh petugas parkir [3]. Keamanan kendaraan juga menjadi masalah dalam sistem pengolaan parkir, sehingga banyak orang bersedia untuk menghabiskan dana yang lebih banyak untuk memastikan kendaraan mereka aman [2]. Masalah keamanan juga terjadi saat melakukan pembayaran parkir dengan cash atau dengan kartu kredit [2].

Untuk mengatasi permasalahan tersebut, pada penelitian ini diusulkan metode pembayaran yang menggunakan sistem pembayaran uang dijital berbasis teknologi Near Field Communication (NFC). Sistem pembayaran uang dijital adalah metode pembayaran yang memungkinkan pengguna melakukan pembayaran untuk barang yang dibelinya menggunakan perangkat mobile yang berjalan suatu aplikasi di dalamnya [4]. Sistem pembayaran yang diusulkan akan 
menggabungkan kemampuan teknologi NFC sebagai sarana pertukaran data dengan teknologi Global Position System (GPS) yang berperan untuk mengetahui lokasi parkir kendaraan. Teknologi NFC dan GPS akan dikendalikan oleh perangkat lunak yang ditanamkan pada perangkat telepon pintar. Cloud wallet dikembangkan pada bagian halaman belakang sistem untuk mendukung sistem parkir pintar. Sistem pembayaran dengan uang dijital ini akan lebih memudahkan pengguna ketika terjadi transaksi [4].

Pada penelitian [2] dinyatakan NFC adalah salah satu teknologi terbaik dan lebih aman untuk sistem pembayaran parkir tanpa menggunakan tiket. Menurut [5], modul NFC telah digunakan secara luas pada saat ini dan bisa menggantikan kebutuhan kartu parkir atau token parkir untuk menciptakan sistem parkir yang lebih cerdas. Pada penelitian [1] dijelaskan NFC merupakan salah satu solusi terbaik untuk membangun sistem pembayaran parkir kendaraan. NFC enable pada perangkat telepon pintar pengguna digunakan sebagai kunci registrasi untuk masuk ke lokasi parkir. Perangkat telepon pintar yang dilengkapi perangkat NFC dan aplikasi berbasis mobile merupakan solusi terbaik untuk menjadi tag NFC yang akan dibaca oleh NFC reader. Tujuan dari makalah ini adalah untuk melaporkan hasil perancangan dan implementasi pembangunan sistem pembayaran parker dengan menggunakan NFC (Near Field Communication) dan GPS (Global Position System) untuk menghasilkan sistem pembayaran cerdas.

\section{Tinjauan Pustaka}

\section{A. Near Field Communication (NFC)}

Near Field Communication (NFC) adalah teknologi komunikasi wireless yang beroperasi pada frekuensi $13.56 \mathrm{MHz}$ yang dapat melakukan perpindahan data antara dua perangkat NFC pada jarak beberapa centimeters dengan kecepatan 424 Kbps. NFC merupakan kelanjutan dari teknologi Radio Frequency Identification (RF-ID) yang merupakan kombinasi dari smartcard dan reader. Teknologi NFC lebih aman disbanding komunikasi lain seperti radio frequency identification, infra red dan Bluetooth karena NFC mempunyai jarak komunikasi yang pendek [6].

Protokol NFC mempunyai dua mode komunikasi yaitu mode komunikasi aktif dan mode komunikasi pasif [7]. Pada mode aktif, inisiator dan target saling berkomunikasi dengan menghasilkan radio frekuensi mereka sendiri untuk transmisi. Dua perangkat NFC pada mode aktif dapat menghasilkan medan radio frekuensi untuk membentuk link komunikasi dua arah untuk mentransfer data [8]. Pada mode pasif, perangkat NFC yang ber-operasi bertindak sebagai target dan tidak menghasilkan frekuensi sendiri. Sementara yang menjadi perangkat inisiator menghasilkan medan radio frekuensi untuk komunikasi dan perangkat target menggunakan kopling induktif untuk menangkap atau mengambil radio frekuensi yang telah dihasilkan inisiator. Transefer data terjadi setelah kedua perangkat saling bermodulasi [8].

Komunikasi pada perangkat NFC yang operasi pada jarak dekat mendekati beberapa centimeters dapat meminimalkan serangan oleh hacker. Mekanisme pendeteksian error pada komunikasi NFC menggunakan Cyclic redundancy Check (CRC) [6]. Pertukaran data antara perangkat NFC dengan tag, diformat menggunakan NFC Data Exchange Format (NDEF). Setiap pesan NDEF (NDEF-Messages) berisi satu atau lebih catatan NDEF (NDEF-Records) [8].

\section{B. NFC Mobile Payment}

NFC mobile phone (NFC-smartphone) adalah perangkat pintar yang digunakan untuk melakukan transaksi pembayaran [9]. Jenis transaksi NFC payment berdasarkan standar contactless smart card ISO/IEC 18092 NFC IP-1 and ISO/IEC 14443 terdiri dari tiga bentuk yaitu [10] : 1). mode write/read pada perangkat NFC untuk membaca dan menulis tag NFC yang mendukung ISO 14443 dan FeliCa schemes, 2). mode komunikasi peer to peer (P2P) yang memungkinkan dua perangkat NFC saling berkomunikasi menggunakan standar NFCIP-1 and LLCP, 3). mode emulation card yang berfungsi membuat perangkat NFC seperti smart card.

NFC payment dibangun oleh lapisan yang mendukung terlaksananya proses layanan transaksi. Lapisan pendukung NFC payment adalah perangkat NFC-smartphone, merchant's POS terminal, dan jaringan mobile yang aman untuk mengirimkan proses terjadinya transaksi [11]. Kunci sukses dari pembangunan NFC payment untuk transaksi pembayaran adalah terdefenisiny dengan jelas hubungan antara lapisan yang membangun NFC payment [12]. Masalah keamanan sangat penting diperhatikan pada sistem pembayaran elektronik. Pada penelitian [13], dijelaskan untuk mengkombinasikan fungsi NFC dengan SIM atotentifikasi untuk membuat transaksi aman. Penelitian [14], telah dirancang sistem kemanan pada transaski kecil pada sistem pembayaran elektronik menggunakan teknikal ubiquitous komponen.

\section{Global Position System (GPS)}

GPS adalah sistem yang melakukan perhitungan lokasi pengguna dengan menggunakan sinyal yang diterima dari satelit GPS. Data dari GPS nantinya akan digabungkan dengan kemampuan Geographic Information System (GIS) dalam 
pengolahan koordinat dan ditampilkan di dalam peta [15]. GPS dalam melakukan perhitungan lokasi dibantu oleh perangkat pembangunnya, yaitu satelit, ground control dan GPS receivers.

\section{METODOLOGI}

Penelitian dilakukan dengan metode penelitian dan pengembangan. Metodologi pengembangan sistem pada penelitian ini dimulai dengan identifikasi masalah lalu dilanjutkan dengan menganalisa kebutuhan system. Proses selanjutnya adalah merancang arsitektur sistem, merancang proses system pemabayaran menggunakan NFC, dan merancang perangkat keras dan merancang perangkat lunak pada sistem. Perancangan perangkat lunak dibangun dengan metode water fall. Pada penelitian ini, pengujian sistem dilakukan dengan metode kotak hitam berdasarkan kebutuhan fungsional sistem yang telah dibangun.

\section{A. Arsitektur Sistem}

Pada penelitian ini, metode parkir yang dijadikan objek penelitian adalah sistem parkir terbuka. Pada sistem parkir terbuka, parkir kendaraan dilakukan di sepanjang sisi jalan tanpa adanya infrastruktur parkir berupa gerbang parkir [1]. Lokasi parkir dipasang wifi dengan SSID unik yang digunakan sebagai ID lokasi parkir. Rancangan arsitektur sistem dapat dilihat pada gambar 1.

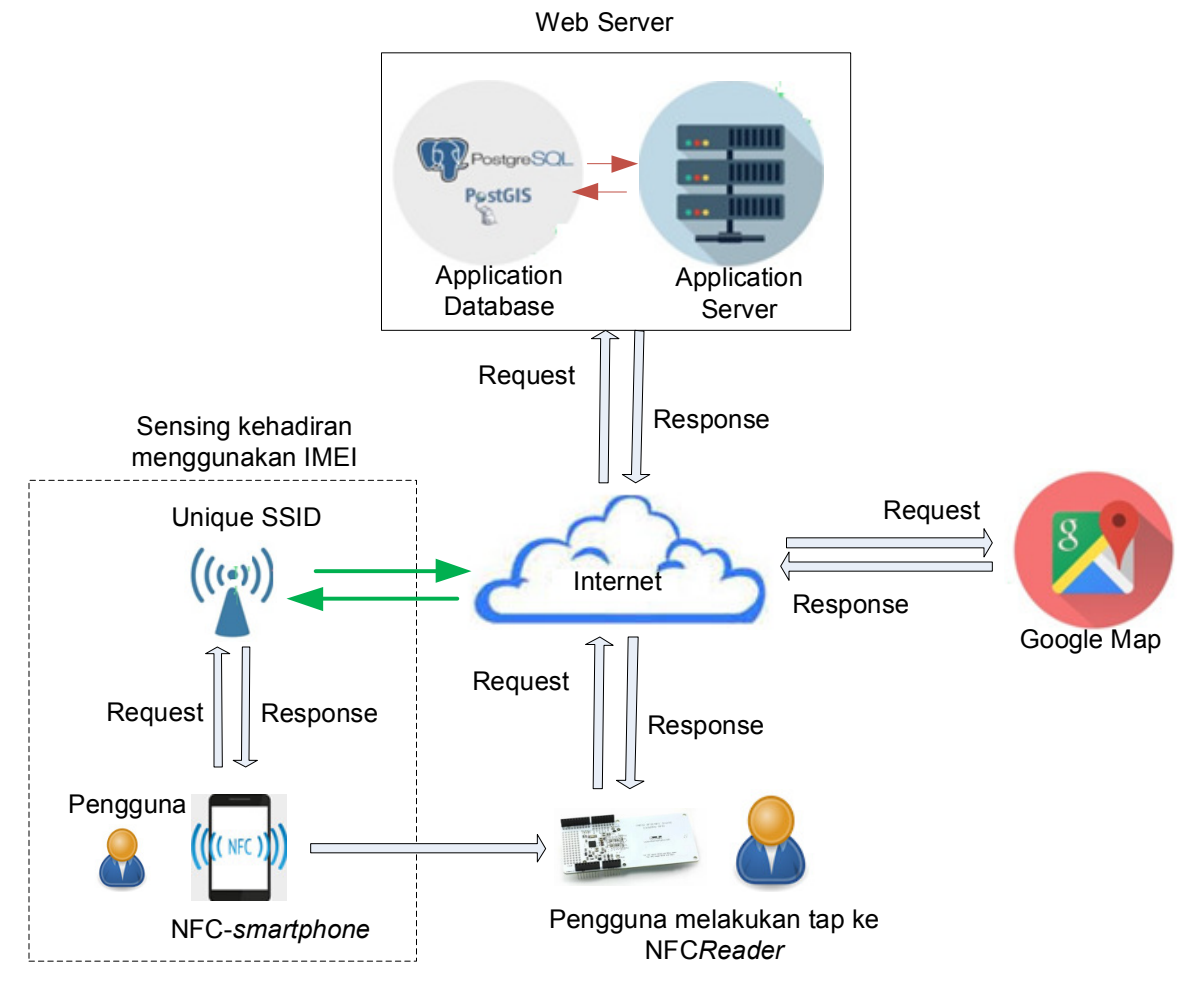

Gambar 1. Arsitektur sistem

Skenario pendaftaran parkir menggunakan teknologi NFC dijelaskan sebagai berikut [16] :

- Saat pengguna mendekati lokasi parkir, aplikasi pada perangkat mobile akan mendeteksi nama lokasi parkir berdasarkan SSID wifi parkir.

- Pengguna memarkirkan kendaraannya di lokasi parkir.

- Pengguna melakukan tap ke NFC reader dengan cara mendekatkan NFC-smartphone ke NFC reader.

- $\quad$ NFC reader membaca data dari NFC-smartphone berupa ID-phone dan diidentifikasikan sebagai identitas dari pengguna. 
- $\quad$ Data ID-phone pengguna ditambah data waktu dan tanggal saat memasuki parkir dikirimkan ke server aplikasi. Server akan memeriksa jumlah uang dijital dari pengguna, jika jumlah uang dijital pengguna yang tersedia terlalu sedikit akan dikeluarkan notifikasi untuk melakukan penambahan saldo uang dijital.

- Pengguna dapat meninggalkan kendaraanya di lokasi parkir. Aplikasi pada perangkat telepon pintar (aplikasi mobile) akan mengirimkan notifikasi kepada pengguna untuk persetujuan pengambilan posisi langitude dan latitude kendaraan. Lokasi kendaraan selanjutnya disimpan ke server.

Skenario pembayaran parkir menggunakan teknologi NFC pada sistem parkir terbuka dijelaskan sebagai berikut :

- Pengguna kembali ke lokasi dimana kendaraanya diparkirkan sebelumnya. Aplikasi mobile akan menunjukkan posisi parkir kendaraan kepada pengguna dengan visualisasi Google Map.

- Pengguna mendekatkan NFC-smartphone ke NFC reader. NFC reader membaca data ID-phone dan mengambil data waktu dan tanggal terakhir. Data ID-phone dan data waktu dan tanggal akan dikirim ke server dan dibandingkan dengan data sebelumnya. Jika data ditemukan maka akan dilakukan proses perhitungan biaya parkir.

- Server membaca uang dijital pengguna dan selanjutnya sistem akan melakukan proses pembayran.

\section{B. Perancangan Perangkat Keras}

Perancangan perangkat keras pada sistem digambarkan dalam bentuk blok diagram. Blok diagram menggambarkan proses dan alur kerja sistem yang dikembangkan. Blok diagram perancangan perangkat keras pada penelitian ini terlihat pada gambar 2. NFC Reader PN532 Shield yang dihubungkan dengan Arduino Uno Board digunakan untuk pembacaan NFC- smartphone. NFC-Reader yang terhubung dengan Arduino dinamakan dengan NFC-Controller. Hubungan antara pin NFC Reader PN532 dengan Arduino Uno dapat dilihat pada tabel 1.

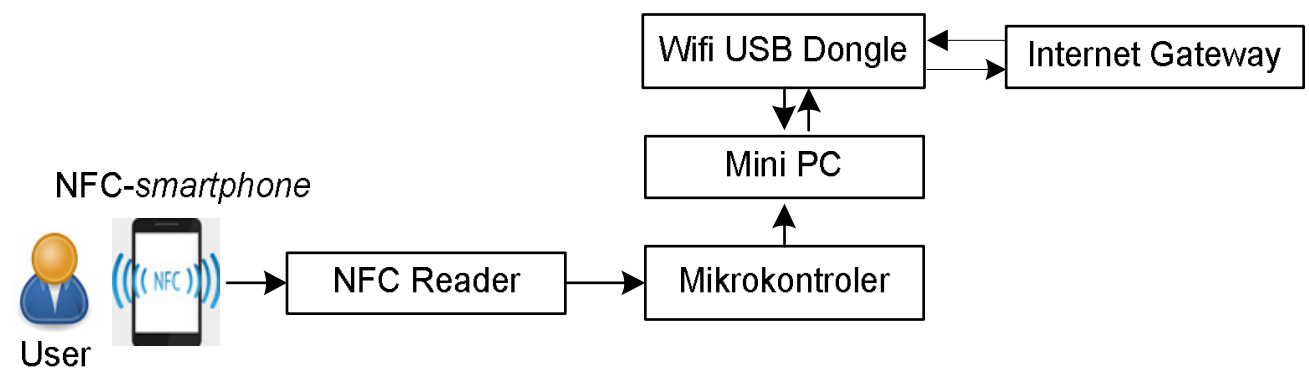

Gambar 2. Blok diagram perangkat keras

TABEL I

Hubungan antara PN532 NFC Shield dengan ArduinoUno

\begin{tabular}{|c|c|c|}
\hline Mode & PN532 Shield v1 & Arduino Uno \\
\hline & VCC & $5 \mathrm{~V}$ \\
\hline & GND & GND \\
\hline $\begin{array}{c}\text { IIC/12C } \\
\text { Mode }\end{array}$ & SDA (Serial Data Address) & A4/SDA \\
\hline & SCL (Serial Clock) & A5/SCL \\
\hline SPI Mode & SCK (Serial Clock) & Pin 13 or ICSP-3 \\
\hline & MISO (Master In Slave Out) & Pin 12 or ICSP-1 \\
\hline & MOSI (Master Out Slace In) & Pin 11 or ICSP-4 \\
\hline & SS (Slave Select) & Pin 10 \\
\hline
\end{tabular}

C. Perancangan Perangkat Lunak

1) Perangkat Lunak Sistem Tertanam

Program perangkat lunak tertanam diletakaan pada Arduino Uno yang berfungsi sebagai mikrokontroler sistem. Perangkat lunak tertanam pada Arduino Uno akan melakukan pengontrolan terhadap pembacaan data NFC oleh NFCController, dan mengirimkan data yang terbaca ke server aplikasi. Perangkat lunak tertanam ini dirancang dengan 
mengikuti flowchart yang telah ditentukan. Proses perancangan perangkat lunak untuk pembacaan data dengan NFC smartphone dilakukan dengan proses HCE. Pada gambar 3 diperlihatkan flowchart proses pembacaan NFC smartphone.

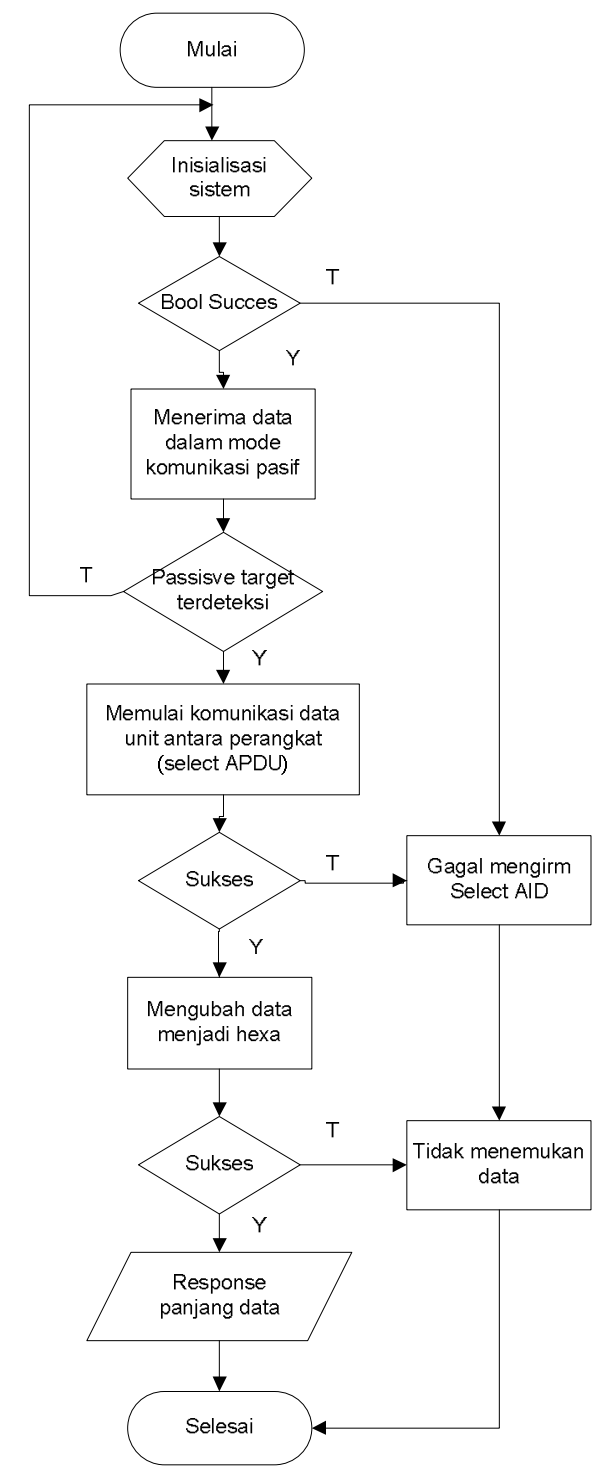

Gambar 3. Flowchart proses pembacaan NFC smartphone

Aplikasi mobile dirancang sesuai dengan fungsional sistem. Fungsional sistem yang dirancang adalah : (a) pengguna dapat melakukan registrasi ke sistem, (b) pengguna dapat mengetahui lokasi kendaraan yang diparkir pada lahan parkir, (c) pengguna dapat mengetahui jumlah biaya parkir secara real time, (d) pengguna dapat membayar parkir kendaraan dengan menggunakan smartphone yang mempunyai fitur NFC enable melalui aplikasi yang terhubung pada sever cloud wallet. Aktivitas sistem smart parking payment digambarkan pada use case diagram. Use case diagram disusun berdasarkan kebutuhan fungsional sistem yang telah didefenisikan. Use case terdiri dari 1 aktor yaitu pengguna dan 4 use case. Gambar dari use case sistem dapat dilihat pada gambar 4. Context diagram sistem ditunjukkan pada gambar 5. 


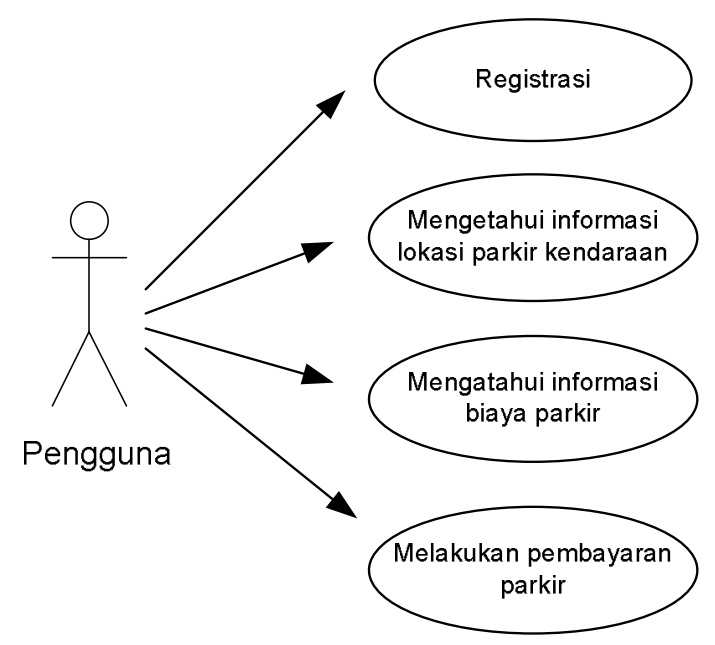

Gambar 4. Use case diagram

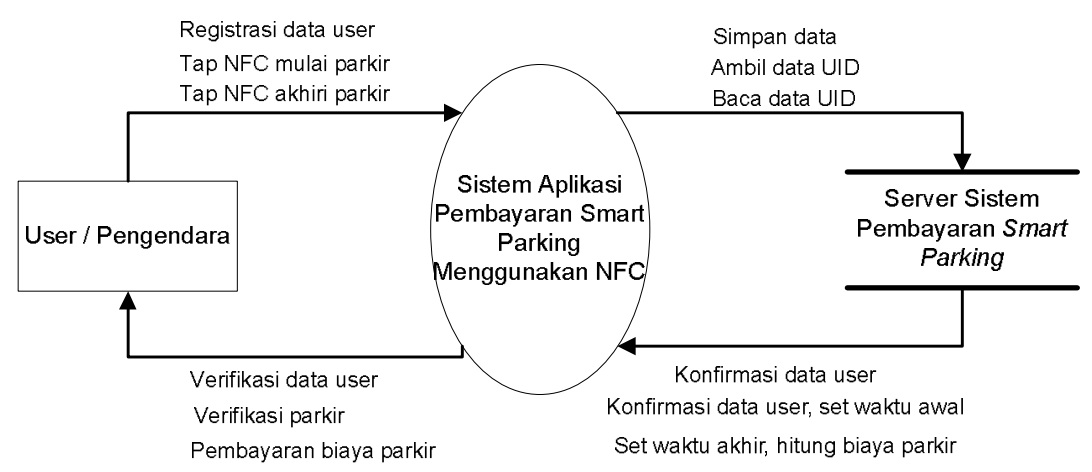

Gambar 5. Context diagram

\section{Perancangan Proses}

Pengguna berperan sebagai entitas eksternal pada sistem. Pengguna dalam sistem ini adalah pengendara kendaraan yang akan melakukan parkir kendaraan mereka. Masing-masing lokasi parkir terdapat wifi dengan SSID nama parkir yang unik. Jika pengguna yang merupakan pengendara memasuki lokasi parkir dan mendapat sinyal dari wifi parkir, secara pervasive sistem akan meminta user untuk registrasi ke sistem. Jika pengendara telah pernah melakukan registrasi pada sistem sebelumya, maka sistem akan meminta konfirmasi data kepada pengendara. Data yang dikirimkan oleh user/pengendara ke sistem adalah UID, username dan nomor kendaraan. Proses yang terjadi pada sistem :

- Memasuki kawasan parkir :

Pengendara melakukan tap NFC smartphone ke NFC reader, data UID dari telepon pintar akan dibaca oleh NFC reader dan dikirim ke server aplikasi. Server aplikasi akan melakukan penyimpanan data ke database aplikasi. Sebelum billing waktu parkir dimulai, sistem akan mengirimkan konfirmasi mengenai kesedian parkir kepada pengendara dalam waktu 10 detik. Jika konfirmasi yang dikirimkan oleh server diterima oleh pengendara, maka proses billing akan dimulai.

- Keluar dari kawasan parkir :

Pengendara melakukan tap NFC smartphone ke NFC reader, data UID dari smartphone akan dibaca oleh NFC reader dan dikirim ke server aplikasi. Server aplikasi akan membandingkan data UID yang diambil dari pengendara dengan data UID yang ada pada server aplikasi. Jika UID ditemukan, server akan melakukan perhitungan biaya 
parkir berdasarkan waktu lama parkir. Server akan mengirimkan biaya parkir kepada pengendara, lalu pengendara akan melakukan pembayaran biaya parkir. Setelah konfirmasi pembayaran dilakukan maka proses selesai.

\section{HASIL DAN PEMBAHASAN}

\section{A. Implementasi Sistem}

Pada penelitian ini, pembangunan sistem pembayaran parkir menggunakan NFC terdiri dari implementasi perangkat keras dan implementasi perangkat lunak. PostgreSQL digunakan sebagai database pada sistem. Pemrograman sistem tertanam menggunakan Processing dan Arduino Uno sebagai mikrokontroler. Pemrograman dan pembangunan antar muka aplikasi mobile dibangun dengan menggunakan Basic4Android dan PHP.

\section{1) Implementasi Perangkat Keras}

Implementasi sistem tediri dari infrastruktur perangkat keras dan perangkat lunak. Semua perangkat keras yang digunakan dalam penelitian ini terhubung menggunakan protocol komunikasi TCP/IP. Arsitektur there-tier client server diterapkan dalam sistem ini untuk memisahkan antara logika aplikasi dan manajemen data. NFC Controller PN532 dengan komunikasi SPI diperlihatkan pada gambar 4.

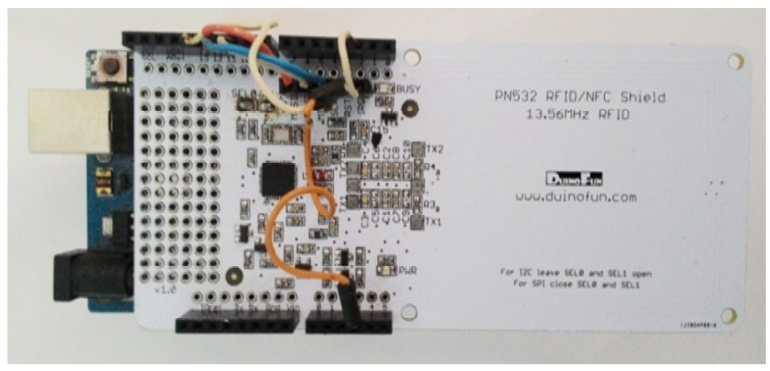

Gambar 4. NFC Controller PN532 dengan komunikasi SPI

2) Implementasi Perangkat Lunak

Pada penelitian ini digunakan beberapa perangkat lunak dalam pembangunan aplikasi dan implementasinya. Dalam tahap pembangunan aplikasi Android digunakan Basic4 Android dari Anywhere Software.

\section{B. Hasil}

Hasil dari perancangan perangkat keras dan perangkat lunak pada penelitian ini, terbentuk sebuah sistem pembacaan NFC dengan perangkat telepon pintar untuk proses pembayaran parkir. Hasil implementasi sistem pada perangkat keras dapat dilihat pada gambar 4. Antarmuka aplikasi mobile pembayaran parkir dibangun dengan menggunakan fitur designer dari Basic4Android. Sesuai dengan keperluan pemakai serta rancangan antarmuka dan proses yang telah dibuat, ada empat hasil yang ditunjukkan dalam paper ini. Implementasi antar muka aplikasi mobile yang akan disajikan adalah : a). Antar muka halaman registrasi; b). Antar muka halaman informasi lokasi kendaraan; c). Antar muka halaman biaya parkir; d). Antar muka halaman pembayaran parkir.

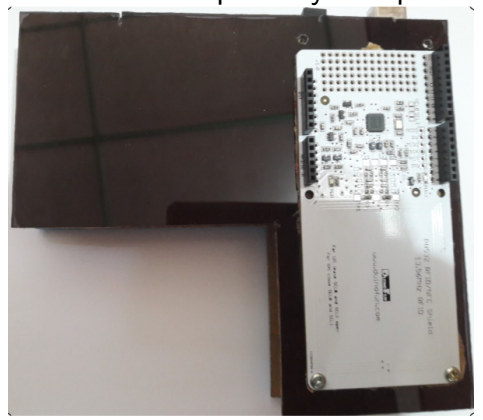

Gambar 4. Implementasi perangkat pembaca NFC Payment 
1) Antar muka halaman registrasi

Halaman antar muka registrasi akan tampil ketika pengguna baru pertama kali masuk ke dalam lokasi parkir. Pengguna akan diminta untuk menginput nama, nomor kendaraan dan jenis kendaraan. Data pengguna akan disimpan di dalam database aplikasi. Aplikasi akan mengambil IMEI perangkat dan digunakan sebagai primary key (PK) pada database. Proses registrasi pada sistem terjadi saat pengguna pertama kali menggunakan aplikasi, selanjutnya sistem secara otomatis akan mengenali pengguna berdasarkan nomor unik IMEl dari perangkat telepon pintar. Antar muka halaman registrasi diperlihatkan pada gambar 5.

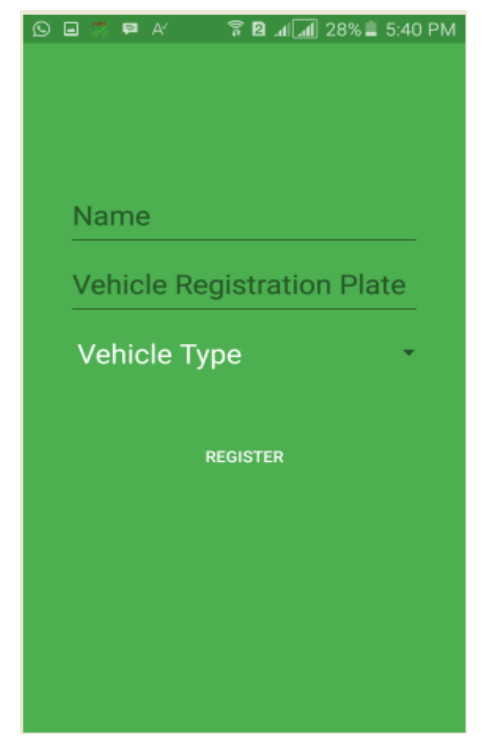

Gambar 5. Antar muka halaman registrasi

2) Antar muka halaman informasi lokasi kendaraan

Halaman antar muka informasi lokasi kendaraan akan menunjukkan lokasi kendaraan yang sedang diparkirkan oleh pengguna. Visualisasi peta ditampilkan pada google map. Data koordinat lokasi parker diambil dari database berdasarkan data langitude dan latitude kendaraan. Antar muka halaman informasi lokasi kendaraan diperlihatkan pada gambar 6.

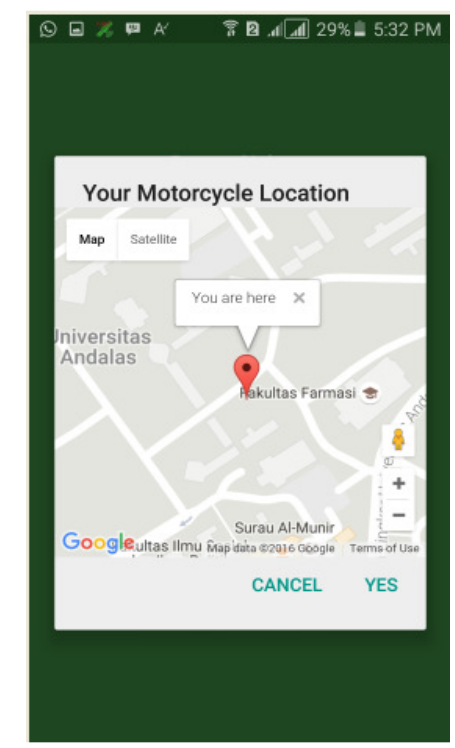

Gambar 6. Antar muka halaman informasi lokasi kendaraan 
3) Antar muka halaman biaya parkir

Halaman antar muka biaya parkir menunjukkan berapa jumlah biaya parkir berdasarkan waktu lamanya parkir dan jenis kendaraan. Lama waktu parkir adalah rentang waktu antara pengguna melakukan tap ke NFC reader saat akan melakukan parkir dengan waktu sekarang yang dihitung di sisi server. Antar muka halaman biaya parkir diperlihatkan pada gambar 7 .

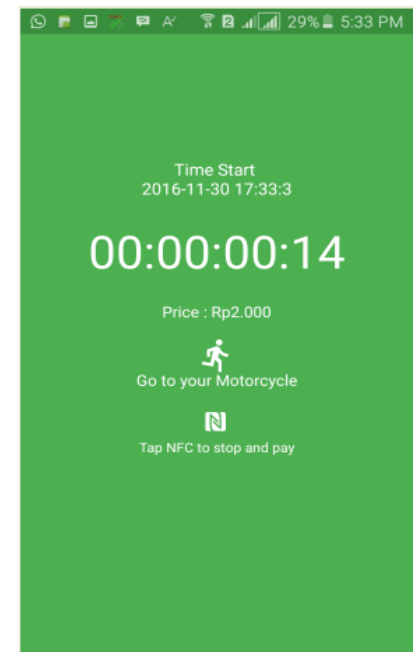

Gambar 7. Antar muka halaman biaya parkir

4) Antar muka halaman pembayaran parkir

Halaman antar muka pembayaran parkir digunakan untuk melakukan pembayaran parkir dengan tap pada perangkat NFC dan konfirmasi pembayaran biaya parkir pada cloud wallet. Halaman ini sekaligus berfungsi untuk mengakhiri transaksi dan keluar dari lokasi parkir. Antar muka halaman pembayaran parkir diperlihatkan pada gambar 8.

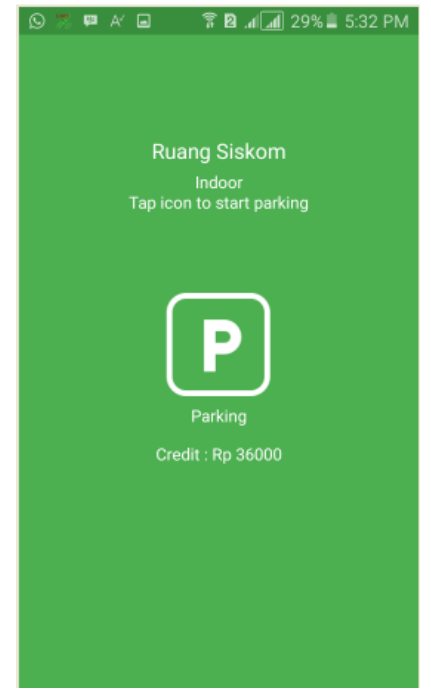

Gambar 8. Antar muka halaman pembayaran parkir 


\section{Pengujian Sistem}

Pengujian sistem dilakukan dengan cara kotak hitam (Black Box testing). Pada pengujian kotak hitam, pengujian aplikasi dilakukan oleh tester berdasarkan kebutuhan fungsional perangkat lunak. Pengujian ini dilakukan berdasarkan 4 kebutuhan fungsional aplikasi yang telah dirancang sebelumnya. Pada gambar 9 diperlihatkan hasil pengujian proses registrasi pada sistem. Proses pengujian dilakukan dengan memasukkan username "Dody" kendaraan motor "BA7654AC", ekspektasi yang diharapkan adalah sistem akan memvalidasi data yang dimasukkan dan meresponnya. Hasil pengujian menunjukkan telah terpenuhinya ekspektasi yang diharapkan. Pengujian untuk melihat waktu proses pembayaran parkir oleh pengguna mendapatkan hasil waktu rata-rata proses pembayaran parkir adalah 0.48 detik. Grafik waktu proses pembayaran parkir diperlihatkan pada gambar 10.

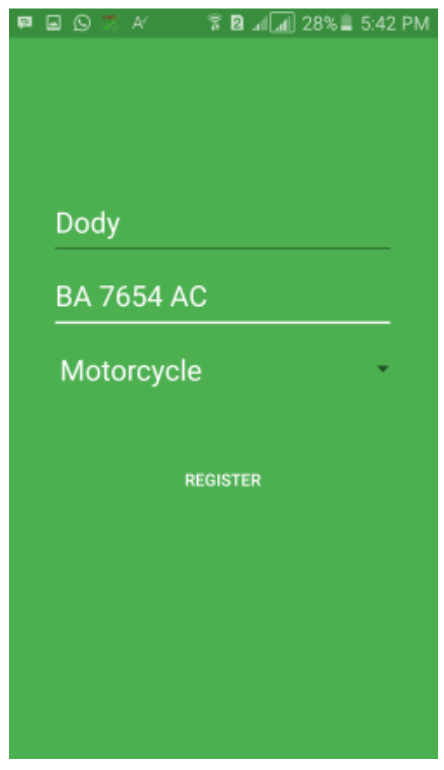

(a)

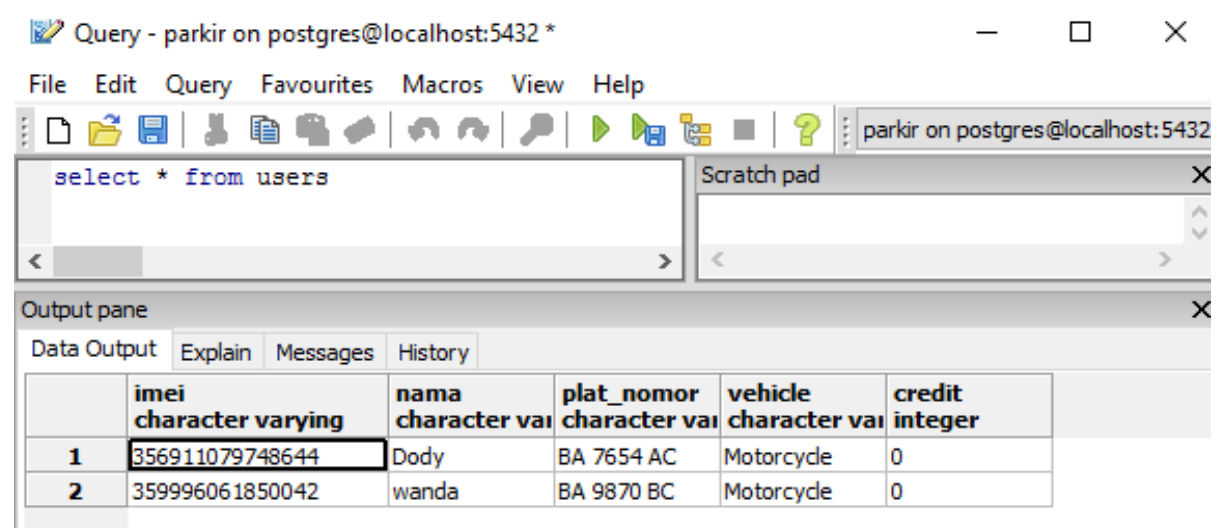

(b)

Gambar 9. Pengujian proses registrasi, (a) Memasukkan data pada proses registrasi, (b) Query SQL data pengguna pada database 


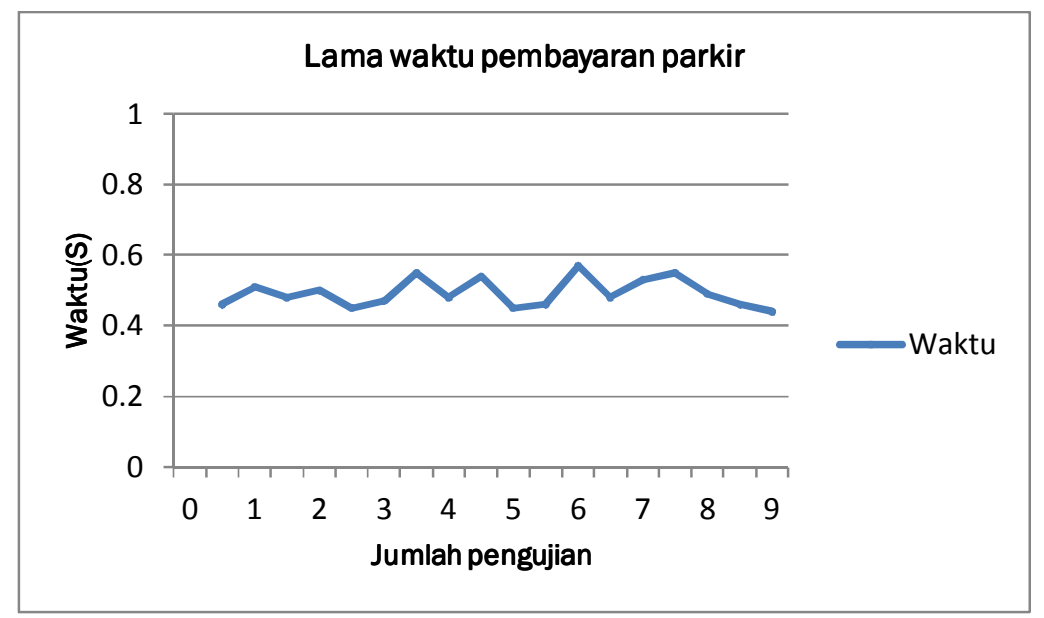

Gambar 10. Grafik waktu pengujian proses pembayaran parker berdasarkan jumlah pengujian

\section{KeSIMPULAN}

Penelitian ini telah berhasil membangun dan mengimplementasikan sistem pembayaran parkir menggunakan NFC melalui aplikasi yang berjalan di sistem operasi Android. Konsep pervasive computing telah berhasil diterapkan dengan basis teknologi Internet of Things (IoT). Rancangan yang dibuat telah diimplementasikan dengan menggunakan Arduino Uno sebagai mikrokontroler. Pemrograman sistem tertanam menggunakan Processing. Pemrograman dan pembangunan antar muka aplikasi mobile dibangun dengan menggunakan Basic4Android, PHP dan PostgreSQL sebagai database. Dari hasil implementasi tersebut dapat dinyatakan bahwa model yang dibuat telah bekerja sesuai dengan yang diharapkan. Model dapat mengetahui lokasi kendaraan yang diparkir pada lahan parkir, jumlah biaya parkir secara real time dan melakukan pembayaran parkir menggunakan smartphone android yang mempunyai fitur NFC enable. Pengujian sistem dilakukan dengan black box testing telah menujukkan system berjalan dengan baik. Proses waktu pembayaran parkir telah efektif dengan waktu rata-rata proses pembayaran selama 0.48 detik. Untuk penelitian selanjutnya disarankan untuk membuat sistem pembayaran parkir yang sekaligus bisa mendeteksi lokasi parkir kosong.

\section{UCAPAN TERIMA KASIH}

Ucapan terima kasih ditujukan kepada Universitas Andalas melalui Program Penelitan Dosen Pemula tahun 2016, No Kontrak : 43/UN.16/Dosen Muda/LPPM/2016.

\section{REFERENSI}

[1] G. Benelli och A. Pozzebon, "Innovative Solutions for the Automatic Payment of Car Parks," vol. Special Issue Volume 1, nr 1, 2013.

[2] "OPEN ACCESS NFC based parking payment system," vol. 5, nr 6, p. 56-59, 2015.

[3] M. Migliore, L. Antonino och M. DI, "Parking pricing for a sustainable transport system," Transportation Research Procedia, vol. 3, nr July, pp. 403412, 2014.

[4] X. Ma och W. Wei, "The Architecture of Mobile Wallet System Based on NFC (Near Field Communication)," Research Journal of Applied Sciences, Engineering and Technology, vol. 7, nr 12, pp. 2589-2595, 2014.

[5] J. Nair, N. Gupta, R. Mahadik och C. Chauhan, "Innovative Smart Car Parking System with NFC Access, ISSN: 2321-0869," vol. 3, nr 4, 2015.

[6] A. Radhakrishnan, "NFC based parking payment system," Int. Journal of Engineering Research and Applications, vol. 5, nr 6, pp. 56-59, June 2015.

[7] T. Igoe, "Beginning NFC: Near Field Communication with," O'Reilly Media, 2014.

[8] C. Bajaj, "Near Field Communication," International Journal of Advanced Research in Computer Science and Software Engineering, p. 8, 2014.

[9] L. Francis och G. Hancke, "On the security issues of NFC enabled mobile phones," International Journal of Internet Technology and Secured Transactions, vol. 2, pp. 336-356, 2010.

[10] NFC Forum, "Essentials for successful NFC mobile ecosystems," 2008. [Online]. Available: www.nfcforum.org/resources/white papers/NFC Forum Mobile NFC Ecosystem White Paper.pdf. [Använd 1210 2016]. 


\section{TEKNOSI, Vol. 03, No. 01, April 2017}

[11] Smart Card Alliance Mobile and NFC Council , "NFC Application Ecosystems: Introduction, Peer-to-Peer, NFC Tags/Posters and Product Label Applications," 2012. [Online]. Available:

http://www.smartcardalliance.org/resources/webinars/nfc_app_ecosystem/20120927_NFC_Application_Ecosystems.pdf. [Använd 20 September 2016].

[12] K. Kadambi, J. Li och A. H. Karp, "Near-field communication-based secure mobile payment service," i proceedings of the 11th International Conference on Electronic Commerce (ICEC), New York, NY, USA, 2009.

[13] W. Chen och P. Hancke, "NFC Mobile Transactions and Authentication Based on GSM Network," i Second International Workshop on Near Field Communication, IEEE, Monaco, 2010.

[14] Y. Wiratama och L. Sharon, "A New Mobile Payment Model for Campus based on NFC Technology," i Second International Workshop on Near Field Communication, 2014.

[15] X. Huang, "“Development and Research of 3G Road Video and Real-time Location Report Module for Vehicles," commissioned by Automotive Research \& Test Center, 2008.

[16] D. Ichwana, "Smart Parking Payment Menggunakan Near Field Communication (NFC)," Seminar Nasional Teknik Elektro (Senter 2016), Bandung, 2016. 